\title{
IMPLEMENTASI SAK-ETAP SEBAGAI UPAYA MENINGKATKAN KUALITAS LAPORAN KEUANGAN DAN PENGARUHNYA TERHADAP TINGKAT KESEHATAN KOPERASI DI KOTA TANGERANG
}

\author{
Triana Zuhrotun Aulia ${ }^{(1)}$ \\ Universitas Muhammadiyah Tangerang \\ trianazuhrotun@umt.ac.id \\ Hamdani $^{(2)}$ \\ Universitas Muhammadiyah Tangerang \\ hamdani_82m@yahoo.com
}

\begin{abstract}
Cooperatives in Indonesia have decreased in quantity and quality. The number continues to decline due to the declining level of health of the cooperative. Improvements that must be done is to carry out cooperative reforms through continuous development so that the quantity of cooperatives increases and the quality of cooperatives rises. One of the good quality cooperatives can be seen from the quality of its financial statements. This study is intended to determine the implementation of Financial Accounting Standards for Entities Without Public Accountability (SAK-ETAP) in order to improve the quality of financial reports and assess the health of cooperatives in cooperatives in Tangerang City. It is hoped that this research will be useful theoretically in the development of science and practical benefits for writers, the community and the management of cooperatives. The research sample is all cooperatives in the city of Tangerang. The variables used in this study consisted of exogenous variables (SAK-ETAP implementation) and intervening variables (financial report quality), and endogenous variables (the level of cooperative health). Data collected through field surveys using questionnaires and direct interviews to get more complete information. To support theoritical argumentation, a literature study was conducted. This research data analysis method uses SEM PLS 4.0 Software with the following stages: testing the measurement model (outer model), namely convergent validity test, discriminant validity test, and composite reliability test. The next step is testing the structural model (inner model) and testing the hypothesis. The results of the study prove that the implementation of SAK ETAP has a significant positive effect on the quality of financial statements and the health level of cooperatives. The quality of financial statements has a significant positive effect on the health level of cooperatives and is a variable that mediates the effect of the implementation of SAK ETAP on the health level of cooperatives.
\end{abstract}

Keywords: implementation of SAK-ETAP, quality of financial statements, level of cooperative health. 


\section{PENDAHULUAN}

\section{Latar Belakang Masalah}

Koperasi adalah badan usaha yang memiliki prinsip keterbukaan, transparansi dan akuntabilitas yang dapat diakui, diterima dan dipercaya baik oleh anggota koperasi khususnya maupun oleh masyarakat pada umumnya. Koperasi telah terbukti tidak hanya memberikan kesejahteraan bagi anggotanya, tapi juga memberikan kontribusi nyata bagi pembangunan ekonomi nasional. Hal ini dapat dilihat dari kontribusi koperasi terhadap Produk Domestik Bruto (PDB), kewirausahaan dan bisnis e-commerce. Secara nasional data mengenai kontribusi koperasi terhadap PDB dapat dilihat dalam gambar berikut:

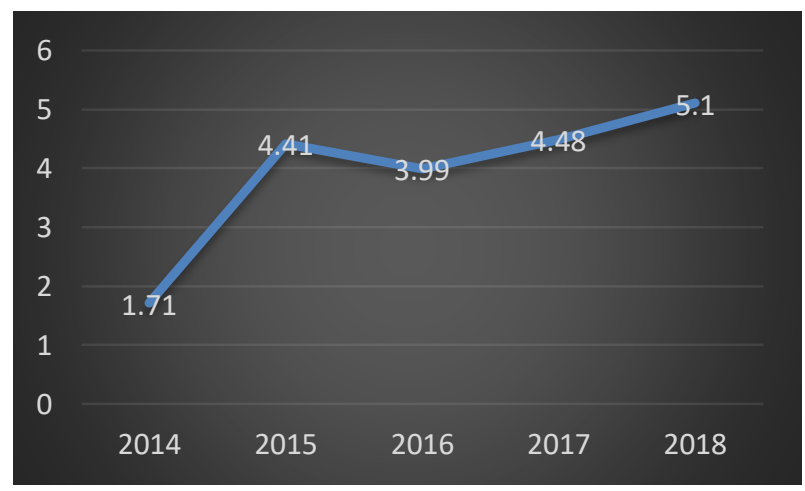

Sumber :

\section{Gambar 1.}

\section{Persentase Kontribusi Koperasi pada Produk Domestik Bruto (PDB)}

Kontribusi koperasi pada PDB memiliki tren yang postitif dimana dari tahun 2014 menyumbang $1,71 \%$, meningkat pada tahun 2015 sebesar $4,41 \%$ (naik sebesar $2,71 \%$ ), sempat mengalami penuruhan pada tahun 2016 $(3,99 \%)$ dan kembali naik pada tahun 2017 $(4,48 \%)$ dan pada tahun $2018(5,1 \%)$.

Peran dan kontribusi koperasi yang penting dan terus meningkat dalam upaya meningkatkan ekonomi secara nasional nyatanya tidak sejalan dengan perkembangan keberadaan koperasi di Indonesia saat ini. Koperasi di Indonesia mengalami penurunan secara kuantitas dan kualitas baik ditingkat nasional maupun daerah. Data yang dihimpun dari Online Data System (ODS) di Kementerian Koperasi dan UKM terhimpun data sebagai berikut:
Tabel 1.

\section{Data Koperasi Aktif dan Non-Aktif selama tahun 2014 - 2018}

\begin{tabular}{|c|r|r|r|}
\hline Tahun & Koperasi Aktif & Koperasi Non-Aktif & Jumlah \\
\hline 2014 & 147.249 & 62.239 & 209.488 \\
\hline 2015 & 150.223 & 61.912 & 212.135 \\
\hline 2016 & 151.170 & 57.025 & 208.195 \\
\hline 2017 & 152.174 & 2.830 & 155.004 \\
\hline 2018 & 126.343 & 25.831 & 152.174 \\
\hline
\end{tabular}

Sumber: http://www.depkop.go.id, 2019.

Menurut data ODS, terjadi penurunan jumlah koperasi secara masif selama tahun 2014 sampai tahun 2018. Tercatat terjadi penurunan dimulaii pada akhir tahun 2016 jumlah koperasi mencapai 208.195 unit yang tahun sebelumnya mencapai 212.135 unit. Tahun 2017 dan 2018 juga mengalami penurunan dengan jumlah masing-masing 155.004 unit dan $152.174 \quad$ unit (http://www.depkop.go.id/data-koperasi) .

Penurunan jumlah koperasi secara nasional juga disumbang oleh koperasi yang berada di Kota Tangerang. Pada bulan Februari 2018, tercatat jumlah koperasi yang masih aktif beroperasi di Kota Tangerang berjumlah 712 unit. Jumlah tersebut menurun dibandingkan data per Desember 2017 sebanyak 962 unit (Tangerangnews.com, 2018).

Penurunan secara kuantitas ini menunjukkan eksistensi koperasi di Kota Tangerang sedang terancam. Menurut Kepala Bidang Koperasi, Dinas Koperasi dan UKM Kota Tangerang Syarifudin HW penurunan jumlah koperasi di Kota Tangerang akibat permasalahan internal serta dampak dari perkembangan perusahaan retail dan minimarket (Tangerangnews.com, 2018).

Pembenahan yang harus dilakukan adalah dilakukannya reformasi koperasi, yaitu melalui pembinaan yang terus-menerus sehingga secara kuantitas jumlah koperasi meningkat dan secara kualitas koperasi ikut terangkat. Salah satu pembenahan dan perbaikan yang penting adalah manajemen pengelolaan koperasi melalui peningkatan kompetensi para pengurus, staf dan pengawas koperasi sangat diperlukan mengingat perkembangan dunia bisnis yang terus berkembang (Hamdani \& Aulia, (2018) dan 
Adiputra (2017)). Berbagai kompetensi dan keahlian yang harus dimiliki para pengurus berguna untuk meningkatkan kualitas koperasi. Kualitas koperasi yang baik salah satunya dapat dilihat dari kualitas laporan keuangan koperasi. Laporan keuangan koperasi seharusnya menerapkan Standar Akuntansi Keuangan sesuai aturan yang berlaku yaitu Standar Akuntansi Keuangan Entitas Tanpa Akuntabilitas Publik (SAK ETAP) merupakan standar pelaporan akuntansi yang dianjurkan kepada entitas yang tidak memiliki akuntabilitas publik signifikan dan menerbitkan laporan keuangan untuk tujuan umum (general purpose financial statement) bagi pengguna eksternal (IAI, 2016).

Ketentuan terkait kepatuhan terhadap SAK ETAP mengacu pada PERMEN KUKM Nomor 12 Tahun 2015 tentang Akuntansi Koperasi Sektor Riil dimana laporan keuangan koperasi harus memenuhi ketentuan dalam penyajian kualitatif laporan keuangan diantaranya adalah kepatuhan terhadap standar SAK ETAP yang harus dinyatakan secara eksplisit dan secara penuh dalam catatan atas laporan keuangan.

Temuan yang diperoleh, SAK ETAP belum banyak dipahami oleh para pengurus koperasi sehingga penyusunan laporan keuangan koperasi masih belum sesuai standar keuangan. Hasil ini ditemukan oleh Yuliza dan Afrizal (2016) yang menemukan belum diterapkannya SAK ETAP di Koperasi Universitas Pasir Pengaraian. Hasil yang sama ditemukan oleh Setiyaningsih (2014) yang meneliti di Koperasi Simpan Pinjam Syariah (KSPS) Makmur Batang belum sesuai SAK ETAP. Djumiko, dkk (2013) menemukan pemahaman pengurus terhadap SAK ETAP sehingga penerapannya dikategorikan sangat rendah.

Dari temuan tersebut, penulis tertarik untuk melakukan penelitian mengenai penerapan atau implementasi SAK-ETAP guna meningkatkan kualitas laporan keuangan koperasi di Kota Tangerang. Diharapkan penelitian ini bermanfaat secara teoritis dalam pengembangan ilmu pengetahuan serta manfaat praktis bagi penulis, masyarakat dan pengurus koperasi. Sampel penelitian adalah seluruh koperasi yang ada di Kota Tangerang.

\section{Tujuan dan Kontribusi Penelitian}

Penelitian ini memiliki tujuan mengetahui implementasi SAK ETAP dalam penyusunan laporan keuangan koperasi pada koperasi di Kota Tangerang. Selain itu menganalisis dan mendapatkan bukti empiris mengenai: pengaruh implementasi SAK-ETAP terhadap kualitas laporan keuangan koperasi serta dampaknya terhadap tingkat kesehatan koperasi pada Koperasi di Kota Tangerang.

\section{LANDASAN TEORI, KAJIAN EMPIRIS DAN HIPOTESIS}

\section{A. Teori Entitas}

Teori Entitas (Entity Theory) merupakan konsep yang memandang entitas dan pemilik modal sebagai unit terpisah. Konsep ini mendasari pengelolaan "stewardship" dan pertanggungjawaban "accountability" pada suatu organisasi atau bisnis yang mengedepankan keberlangsungan usaha dan informasi keuangan usaha untuk menjaga hubungan yang baik dengan para pemegang ekuitas. Konsep entitas berlaku untuk firma, perusahaan perseorangan, korporasi (baik berupa perseroan maupun nonperseroan), serta perusahaan kecil dan besar. (Paton, 1962 dalam Suwardjono, 2013).

Teori entitas ini memandang entitas sebagai unit yang terpisah dari pemilik modal bagi entitas tersebut. Dari perspektif ini, akuntansi memiliki kepentingan dengan pelaporan keuangan unit usaha (entitas) bukan pemilik. Secara tidak langsung kesatuan usaha menjadi kesatuan pelapor (reporting entity) yang bertanggungjawab kepada pemilik. Dengan demikian, transaksi/kejadian yang dicatat dan dipertanggungjawabkan adalah transaksi yang melibatkan entitas. Entitas dianggap bertindak atas nama kepentingannya sendiri terpisah dari pemilik.

Pendekatan ini berorientasi pada pengguna daripada berorientasi pada perusahaan. Concepts Study Committe tahun 1964 dari American Accounting Association untuk konsep entitas bisnis mendukung pandangan ini, dengan menyatakan bahwa 
batasan-batasan dari entitas ekonomi semacam itu dapat diidentifikasikan:

a. Dengan menentukan individu atau kelompok yang berkepentingan, dan

b. Dengan menentukan hakikat dari kepentingan individu atau kelompok tersebut

Pendekatan kedua ini membenarkan kemungkinan ekspansi data yang bisa terjadi karena lingkup akuntansi yang baru ketika akuntansi berusaha untuk memenuhi kebutuhan informasi potensial dari semua pengguna. Konsep entitas umumnya diterapkan untuk firma, perusahaan perseorangan, korporasi (baik berupa perseroan maupun nonperseroan), serta perusahaan kecil dan besar.

\section{B. Laporan Keuangan Koperasi}

Laporan keuangan adalah suatu penyajian terstruktur dari posisi keuangan dan kinerja keuangan suatu entitas (IAI, 2015). Laporan keuangan merupakan informasi penting bagi setiap organisasi, baik perusahaan yang berorientasi pada laba maupun organisasi nirlaba. Menurut Kieso (2013;2), Laporan keuangan merupakan sarana yang bisa digunakan oleh entitas untuk mengkomunikasikan keadaan terkait dengan kondisi keuangannya kepada pihak-pihak yang berkepentingan baik yang berasal dari internal entitas maupun eksternal entitas. Berdasarkan uraian tersebut dapat disimpulkan bahwa laporan keuangan merupakan bentuk pertanggungjawaban keuangan perusahaan atas suatu aktivitas dalam menilai kondisi keuangan perusahaan.

Ketentuan umum mengenai laporan keuangan koperasi mengacu pada PERMEN KUKM Nomor 12 Tahun 2015 tentang Akuntansi Koperasi Sektor Riil dimana pemakai laporan keuangan koperasi adalah anggota koperasi, pengurus, pengawas serta stakeholder lain (pemerintah, kreditur dan pihak lain yang berkepentingan) maka laporan keuangan harus memenuhi ketentuan dalam penyajian kualitatif laporan keuangan, antara lain:

a. Karakteristik spesifik laporan keuangan koperasi antara lain adalah:
1) Merupakan bagian
dari laporan pertanggungjawaban pengurus selama satu periode akuntansi,

2) Ditujukan untuk pihak internal maupun eksternal koperasi.

3) Mempunyai daya guna bagi para anggotanya

b. Kepatuhan terhadap standar akuntansi harus dinyatakan secara ekspilist dalam catatan atas laporan keuangan.

c. Laporan keuangan harus disusun atas dasar kelangsungan usaha (going concern)

d. Komponen laporan keuangan koperasi (SAK ETAP); Neraca, Perhitungan Hasil Usaha, Laporan Perubahan Ekuitas., Laporan Arus Kas dan Catatan Atas Laporan Keuangan;

Penyajian informasi laporan keuangan koperasi harus memperhatikan ketentuan SAK-ETAP yang merupakan informasi kualitatif antara lain: Dapat dipahami (understandable), Relevan (relevance), Keandalan (reliable), Dapat Dibandingkan (comparable), Tepat Waktu (timely).

\section{SAK ETAP}

\section{Pengertian SAK ETAP}

Standar Akuntansi Keuangan untuk Entitas Tanpa Akuntanbilitas Publik (SAK ETAP) merupakan standar pelaporan akuntansi yang dianjurkan kepada entitas yang tidak memiliki akuntabilitas publik signifikan; dan menerbitkan laporan keuangan untuk tujuan umum (general purpose financial statement) bagi pengguna eksternal. Yang dimaksud entitas tanpa akuntabilitas publik adalah entitas yang:

a. Tidak memiliki akuntabilitas publik signifikan

b. Menerbitkan laporan keuangan untuk tujuan umum (general purpose financial statement) bagi pengguna eksternal (pemiilik yang tidak terlibat langsung dalam pengelolaan usaha, kreditur, dan lembaga pemeringkat kredit).

Sedangkan entitas memliki akuntabilitas publik signifikan jika:

a. Entitas telah mengajukan pernyataan pendaftaran, atau dalam proses pengajuan pernyataan pendaftaran, padatoritas pasar modal atau regulator lain untuk tujuan penerbitan efek di pasar modal; atau

b. Entitas menguasai aset dalam kapasitas 
sebagai fidusia untuk sekelompok besar masyarakat, seperti bank, entitas asuransi, pialang dan atau pedagang efek, dana pensiun reksa dana dan bank investasi.

Entitas yang memiliki akuntabilitas publik siginifikan dapat menggunakan SAK ETAP jika otoritas berwenang membuat regulasi mengizinkan penggunaan SAK ETAP.

\section{Tujuan dan Manfaat SAK ETAP}

Tujuan SAK ETAP adalah memberikan kemudahan karena lebih sederhana dibandingkan dengan SAK- IFRS yang dinilai lebih rumit untuk dipahami serta diterapkan bagi sebagian besar entitas usaha di Indonesia yang berskala kecil dan menengah. SAK ETAP sehingga lebih mudah dalam implementasinya namun tetap memberikan informasi yang handal dalam penyajian laporan keuangan.

SAK ETAP memiliki beberapa manfaat untuk diterapkan:

a. Diharapkan perusahaan kecil, menengah, mampu untuk:

1) Menyusun laporan keuangannya sendiri.

2) Dapat diaudit dan mendapatkan opini audit.

Sehingga dapat menggunakan laporan keuangannya untuk mendapatkan dana (misalnya dari Bank) untuk pengembangan usaha.

b. Lebih sederhana dibandingkan dengan PSAK - IFRS sehingga lebih mudah dalam implementasinya.

c. Tetap memberikan informasi yang handal dalam penyajian laporan keuangan.

\section{Karakteristik SAK ETAP}

Karakteristik yang spesifik mengenai SAK ETAP adalah sebagai berikut:

a. SAK ETAP adalah standar akuntansi keuangan untuk Entitas Tanpa Akuntabilitas Publik (ETAP). ETAP adalah entitas yang:

1) Tidak memiliki akuntabilitas publik signifikan; dan

2) Menerbitkan laporan keuangan untuk tujuan umum (general purpose financial statement) bagi pengguna eksternal. b. SAK ETAP menggunakan acuan IFRS untuk Small Medium Enterprises.

c. SAK ETAP lebih sederhana dibandingkan SAK Umum dalam hal:

1) Aset tetap, tidak berwujud menggunakan harga perolehan.

2) Entitas anak tidak dikonsolidasi tetapi sebagai investasi dengan metode ekuitas.

d. SAK ETAP mengacu pada praktik akuntansi yang saat ini digunakan

e. Kualitatif informasi laporan keuangan:

1) Dapat Dipahami,

2) Relevan,

3) Materialitas,

4) Keandalan,

5) Substansi Mengungguli Bentuk

6) Pertimbangan Sehat,

7) Kelengkapan,

8) Dapat Dibandingkan,

9) Tepat Waktu,

10) Keseimbangan antara Biaya dan Manfaat.

f. SAK ETAP tidak mengijinkan pengakuan pos-pos dalam neraca yang tidak memenuhi definisi aset atau kewajiban dengan mengabaikan apakah pos-pos tersebut merupakan hasil dari penerapan "matching concept".

g. Saling hapus tidak diperkenankan atas aset dengan kewajiban, atau penghasilan dengan beban, kecuali disyaratkan atau diijinkan oleh SAK ETAP.

\section{Tingkat Kesehatan Koperasi}

1. Pengertian Kesehatan Koperasi

Menurut Peraturan Menteri Negara

Koperasi Dan Usaha Kecil dan Menengah Republik Indonesia Nomor: 35.3/Per/M. KUKM/X/2007 tentang Pedoman Penilaian Kesehatan Koperasi Jasa Keuangan Syariah dan Unit Jasa Keuangan Syariah, kesehatan koperasi adalah kondisi atau keadaan koperasi dimana Koperasi dinyatakan sehat, cukup sehat, kurang sehat dan tidak sehat. Aspek kesehatan koperasi secara garis besar dapat dilihat dari dua aspek, yaitu aspek kinerja keuangan, serta kelembagaan dan manajemen (Sukmana dan Mulyati, 2015);

a. Aspek Kinerja Keuangan: Koperasi mampu melakukan penggalangan, 
pengaturan, penyaluran, dan penempatan dana yang baik, teliti, hati-hati, dan benar, sehingga berlangsung kelancaran arus pendanaan dalam pengelolaan kegiatan usaha.

b. Aspek Kelembagaan dan Manajemen: Koperasi memiliki kesiapan untuk melakukan operasinya dilihat dari sisi kelengkapan legalitas, aturan-aturan, dan mekanisme organisasi dalam perencanaan, pelaksanaan, pendampingan dan pengawasan, Sumber Daya Manusia, permodalan, sarana, dan prasarana kerja.

Tujuan dilakukan penilaian kesehatan Koperasi adalah sebaga berikut:

a. terwujudnya pengelolaan Koperasi yang sehat dan sesuai ketentuan peraturan perundang-undangan;

b. terwujudnya pelayanan prima kepada pengguna jasa koperasi;

c. meningkatnya citra dan kredibilitas kegiatan usaha simpan pinjam oleh koperasi sebagai lembaga keuangan yang mampu mengelola kegiatan usaha simpan pinjam sesuai dengan peraturan perundang-undangan;

d. terjaminnya aset kegiatan usaha simpan pinjam oleh koperasi sesuai dengan peraturan perundang-undangan;

e. meningkatnya transparansi dan akuntabilitas pengelolaan kegiatan usaha simpan pinjam oleh koperasi;

f. dan meningkatnya manfaat ekonomi anggota dalam kegiatan usaha simpan pinjam oleh koperasi.

\section{E. Penilaian Kesehatan Koperasi \\ a. Hasil Penilaian Kesehatan Koperasi}

Skor atau hasil penilaian kesehatan koperasi diklasifikasikan dalam 4 (empat) kategori, yaitu:

1) sehat, jika hasil penilaian diperoleh total skor $80,00<x<100$

2) cukup sehat, jika hasil penilaian diperoleh total skor $66,00<\mathrm{x}<$ 80,00 ;

3) dalam pengawasan, jika hasil penilaian diperoleh total skor $51,00<\mathrm{x}<66,00$; dan

4) dalam pengawasan khusus, jika hasil penilaian diperoleh total skor $0<\mathrm{x}<$ 51,00 .

\section{b. Komponen dan Bobot Penilaian Kesehatan Koperasi}

Penilaian kesehatan koperasi pada penelitian ini didasarkan pada Peraturan Menteri Negara Koperasi Dan Usaha Kecil dan Menengah Republik Indonesia Nomor: 35.3/Per/M.KUKM/X/2007 tentang Pedoman Penilaian Kesehatan Koperasi Jasa Keuangan Syariah dan Unit Jasa Keuangan Syariah, Indikator yang dinilai adalah aspek permodalan, aspek kualitas aktiva produktif, aspek manajemen, aspek efisiensi dan aspek likuiditas, aspek kemandirian danpertumbuhan, serta jati diri koperasi serta kepatuhan prinsip syariah. Indikator yang digunakan untuk menilai tingkat kesehatan koperasi pada penelitian ini hanya 5 aspek yaitu; aspek permodalan, aspek kualitas aktiva produktif, aspek manajemen, aspek efisiensi dan aspek likuiditas, aspek kemandirian dan pertumbuhan. Hal ini dilakukan mengingat tidak semua koperasi diKota Tangerang menerapkan prinsip syariah.

\section{KERANGKA BERPIKIR}

Teori entitas menyatakan bahwa entitas (unit usaha) dianggap bertindak atas nama kepentingannya sendiri terpisah dari pemilik. Sebagai unit yang terpisah dari pemilik modal bagi entitas tersebut maka entitas harus bertanggung jawab terhadap pemilik melalui sarana laporan keuangan. Dari perspektif ini, koperasi yang merupakan unit usaha yang sumber dananya dari anggota dan masyarakat harus mempertanggungjawabkan kepercayaan pengelolaan modal dari anggota dan masyarakat melalui laporan keuangan koperasi.

Kualitas laporan keuangan yang disampaikan kepada pemilik menjadi suatu keharusan sehingga penyusunannya harus sesuai dengan standar yang berlaku yaitu SAK ETAP. Afandi (2017) dan Fanani (2009) menyatakan bahwa Implementasi SAK ETAP mempengaruhi kualitas laporan keuangan. Penyusunam laporan keuangan dilakukan sebagai bentuk pertanggungjawaban bagi pengurus koperasi kepada anggota koperasi dan masyarakat. Selain itu, laporan keuangan yang disusun oleh pengurus koperasi menjadi indikator penilaian tingkat kesehatan koperasi dari aspek keuangan. Semakin baik kualitas 
laporan keuangan, semakin baik penilaian tingkat kesehatan koperasi. Konsep pemikiran di atas digambarkan dalam kerangka pemikiran akan terlihat sebagai berikut:

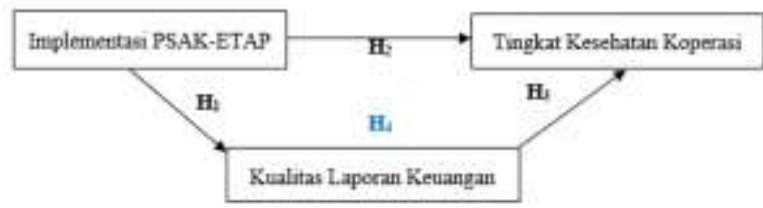

Gambar 2. Kerangka Pemikiran

\section{METODE PENELITIAN}

\section{Desain Penelitian}

Metode penelitian ini menggunakan metode asosiatif dengan pendekatan kuantitatif dengan tujuan menjelaskan hubungan kasual dan pengaruh antara variabel melalui pengujian hipotesis (Sugiyono, 2010:56). Metode pengumpulan data adalah dokumentasi. Penelitian ini menggunakan data kuantitatif. Jenis data yang digunakan adalah data primer dan data sekunder. Data primer berupa data yang diperoleh langsung dari responden berupa jawaban atas kuesioner, data sekunder berupa laporan keuangan koperasi dengan mengambil sumber data koperasi yang diperoleh dari Dinas Koperasi.

Populasi yang digunakan dalam penelitian ini adalah seluruh koperasi yang berada di Kota Tangerang. Adapun sampel ditentukan berdasarkan metode purposive sampling, yaitu menggunakan kriteria tertentu. Adapun kriteria sampel yang digunakan yaitu koperasi di Kota Tangerang yang terdaftar Online Data System (ODS) di Kementerian Koperasi dan UKM dengan status sudah bersertifikat dan membuat laporan keuangan koperasi setiap Rapat Anggota Tahunan (RAT). si dan UKM Kota Tangerang.

Metode pengumpulan data yang digunakan dalam penelitian ini adalah: kuesioner (angket), wawancara, observasi, dokumentasi dan penelusuran kepustakaan (library research).

\section{Definisi dan Operasionalisasi Variabel}

Pengukuran variabel dilakukan berdasarkan tingkat relevan dan efektifitas, dengan menggunakan skala likert.
1. Variabel bebas (variabel eksogen) dalam penelitian ini adalah Implementasi SAK ETAP. Implementasi SAK ETAP merupakan pengukuran penerapan SAK ETAP pada penyusunan laporan keuangan koperasi. Variabel ini diukur dengan pertanyaan/pernyataan dengan mengacu pada indikator yang diatur dalam SAK ETAP (Martani, 2015) yaitu:

a. Pernyataan kepatuhan terhadap SAK ETAP;

b. Komponen Laporan Keuangan lengkap sesuai SAK ETAP;

c. Pos-pos dalam laporan Neraca sesuai ketentuan SAK ETAP;

d. Pos-pos dalam laporan Perhitungan Hasil Usaha sesuai ketentuan SAK ETAP;

e. Pos-pos dalam laporan perubahan ekuitas sesuai ketentuan SAK ETAP;

f. Pos-pos dalam laporan arus kas sesuai ketentuan SAK ETAP;

g. Pos-pos dalam Catatan Atas Laporan Keuangan (CALK) sesuai ketentuan SAK ETAP

2. Variabel terikat (variabel endogen) dalam penelitian ini adalah tingkat kesehatan koperasi. Tingkat kesehatan koperasi adalah kondisi atau keadaan koperasi dimana Koperasi dinyatakan sehat, cukup sehat, kurang sehat dan tidak sehat. Variabel ini diukur dengan pertanyaan/ pernyataan dengan mengacu pada Peraturan Menteri Koperasi Negara Koperasi dan Usaha Kecil dan Menengah nomor 35.3/Per/M.KUKM/X/2007, yaitu:
a. Aspek Permodalan;
b. Aspek kualitas aktiva produktif;
c. Aspek manajemen;
d. Aspek efisiensi;
e. Aspek likuiditas;
f. Aspek kemandirian dan kemandirian.
g. Aspek Jatidiri Koperasi

3. Varibel intervening dalam penelitian ini adalah kualitas laporan keuangan. Kualitas laporan keuangan adalah informasi keuangan yang relevan (relevance) dan merepresentasi secara tepat apa yang direpresentasikan (faithful representation), 
kegunaan informasi keuangan dapat ditingkatkan jika informasi tersebut terbanding (comparable), terverifikasi (verifiable), tepat waktu (timely), dan terpaham (understandable) (IAI, 2016). Variabel ini diukur dengan pertanyaan/pernyataan dengan mengacu pada indikator karakteristik kualitatif laporan keuangan (Martani, 2015) :

a. Relevan (relevance);

b. Andal (reliable, faithfull representation, verifiable);

c. Dapat dibandingkan (comparable);

d. Dapat dipahami (understandable).

\section{Metode Analisis Data}

Metode analisis dalam penelitian ini menggunakan Partial Least Square (PLS). Berikut ini tahapan pengujian yang dilakukan dengan menggunakan partial least square (PLS):

a. Pengujian Model Pengukuran (Outer Model)

Tujuan adalah untuk menguji reliabilitas dan validitas item atau indikator yang membentuk konstruk (Ghozali dan Latan, 2014). Pengujian outer model dengan indikator refleksif dievaluasi menggunakan tiga pengujian yaitu: uji convergent validity, uji discriminant validity, dan uji Composite reliability.

b. Pengujian Model Struktural (Inner Model)

Tujuan dilakukanya pengukuran model struktural dimaksudkan untuk mengetahui pengaruh antara variabel atau konstruk di dalam model (Ghozali dan Latan, 2014:15). Inner model atau model struktural dievaluasi dengan tahapan berikut: uji Adjusted R-Squares, uji QSquare, uji Effect Size $\left(f^{2}\right)$ atau partial Ftest dan uji Fit Model.

c. Pengujian Hipotesis

Hipotesis 1.

Implementasi SAK ETAP berpengaruh terhadap kualitas laporan keuangan. Model struktural untuk menguji hipotesis 1 sebagai berikut:

$$
\mathrm{KLK}=\gamma_{1.1} \mathrm{SAK}+\zeta_{1}
$$

\section{Hipotesis 2.}

Implementasi SAK ETAP berpengaruh terhadap tingkat kesehatan koperasi

Model struktural untuk menguji hipotesis 2 sebagai berikut:

$$
\mathrm{TKK}=\beta_{2.1} \mathrm{SAK}+\zeta_{2}
$$

\section{Hipotesis 3.}

Kualitas laporan keuangan berpengaruh terhadap tingkat kesehatan koperasi

Model struktural untuk menguji hipotesis 2 sebagai berikut:

$$
\mathrm{TKK}=\beta_{3.1} \mathrm{KLK}+\zeta_{2}
$$

\section{Hipotesis 4.}

Kualitas laporan keuangan memoderasi pengaruh implementasi SAK ETAP terhadap tingkat kesehatan koperasi

Model struktural untuk menguji hipotesis 3 sebagai berikut:

$$
\mathrm{TKK}=\beta_{4.1} \mathrm{SAK}+\mathrm{SAK} \cdot \mathrm{KLK}+\zeta_{2}
$$

\section{Keterangan:}

KLK = Kualitas laporan keuangan

SAK = Implementasi SAK ETAP

TKK = Tingkat kesehatan koperasi.

$\beta_{2.1}=$ Koefisien regresi antara variabel laten endogen (TKK) dengan variabel laten endogen (SAK) dari $\eta_{1}$ ke $\eta_{2}$ (beta 2.1)

$\beta_{3.1}=$ Koefisien regresi antara variabel laten endogen (TKK) dengan variabel laten endogen (KLK) dari $\eta_{1}$ ke $\eta_{2}$ (beta 3.1)

$\beta_{4.1}=$ Koefisien regresi antara variabel laten endogen (SAK, SAK.KLK) dengan variabel laten endogen (TKK) dari $\eta_{1}$ ke $\eta_{2}$ (beta 4.1)

$\gamma_{1.1}=$ Koefisien regresi antara variabel laten exogen (SAK) dengan variabel laten endogen (KLK) dari $\xi_{1}$ ke $\eta_{1}$ (gama 1.1

$\zeta_{1}=$ Residual regression (zeta 1) variabel endogen.

\section{HASIL DAN PEMBAHASAN}

\section{Hasil Penelitian}

\section{a. Distribusi Kuesioner}

Sampel dalam penelitian ini adalah pengurus koperasi di Kota Tangerang. 
Kuisioner yang disebar sebanyak 100 kuesioner, kuesioner yang kembali sebanyak 68. Kuesioner yang dapat diolah sebanyak 60, kuesioner tidak lengkap sebanyak 8 kuesioner.

\section{b. Demografi Responden}

Berdasarkan jenis kelamin, responden terdiri dari laki-laki sebanyak 42 atau $70 \%$ sisanya adalah wanita. Menurut jabatan didominasi oleh staf atau pegawai biasa sebanyak 26 atau 43\%. Berdasarkan pendidikan, mayoritas adalah S1 sebanyak 29 orang atau $48 \%$ dengan didominasi latar belakang keilmuan adalah manajemen sebanyak 30 orang atau 50\%. Berdasarkan lamanya bekerja mayoritas telah bekerja lebih dari 5 tahun sebanyak 24 orang atau $40 \%$.

\section{c. Hasil Analisis Data}

1. Hasil Evaluasi Model Pengukuran

a) Convergent validity; Nilai loading masing-masing indikator reflektif telah memenuhi syarat validitas konvergen yaitu sebagian indikator di atas 0.7 dan signifikan. Seluruh indikator memiliki cross-loading yang rendah ke variabel laten lain sehingga menunjukkan convergent validity yang baik.

b) Discriminant Validity; Nilai average variance extracted (AVE) variabel Implementasi SAK ETAP (SAK), kualitas laporan keuangan (KLK) dan Tingkat kesehatan koperasi (TKK) telah memenuhi syarat yaitu $>0.50$. Maka, data yang diperoleh menunjukkan discriminant validity yang baik.

c) Composite Reliability; Masing-masing konstruk dengan indikator reflektif sangat reliabel karena memiliki composite reliability dan cronbach alpha yang tinggi yaitu di atas 0.7. Maka data dalam model penelitian ini sangat reliabel.

2. Hasil inner model atau model struktural

a) Adjusted R-Squared; Nilai Adjusted $R$ Squared variabel TKK sebesar 0,562 menunjukan bahwa variasi TKK dapat dijelaskan oleh variasi SAK dan KLK sebesar 56,2\% dan sisanya sebesar $43,8 \%$ dipengaruhi oleh variabel lain diluar model penelitian. Nilai Adjusted $R$-Squared ini termasuk kategori moderat. Adjusted R-Squared variabel KLK sebesar 0,253 menunjukan bahwa variasi RAT dapat dijelaskan oleh variasi SAK sebesar $25,3 \%$ dan sisanya sebasar $74.7 \%$ dipengaruhi oleh variabel lain diluar model penelitian. Nilai Adjusted $R$-Squared ini termasuk kategori lemah.

b) Q-Square; Hasil estimasi model penelitian menunjukan validitas prediktif yang baik yaitu 0,603 (TKK) dan 0,312 (KLK), karena lebih besar dari nol.

Tabel 1.

Latent variable coefficients

\begin{tabular}{lccc}
\hline & SAK & KLK & TKK \\
\hline Adjusted R-squared & & 0,253 & 0,562 \\
\hline$Q$-squared coefficients & & 0.312 & 0.603 \\
\hline
\end{tabular}

Sumber: Data diolah, 2019.

c) Effect Size (f2); Hasil estimasi menunjukan effect size SAK sebesar 0,582, KLK sebesar 0.503, dan TKK sebesar 0.677. Effect size sebesar $0,582,0,503$ dan 0,677 tergolong memiliki effect size besar karena di atas 0.35. Artinya SAK mempunyai peran penting dalam perspektif praktis dalam meningkatkan KLK. Begitupun KLK, tentu berperan penting pada perspektif praktis dalam meningkatkan TKK.

Tabel 2.

Effect Sizes for Path Coefficients

\begin{tabular}{ccc} 
SAK & KLK & TKK \\
\hline 0,582 & 0,503 & 0,677 \\
\hline
\end{tabular}

Sumber: Data diolah, 2019

\section{Hasil Uji Hipotesis}

Berdasarkan hasil perhitungan uji SEM PLS menunjukan jalur SAK terhadap KLK dengan nilai $p$ value $<0.01$ dan nilai koefisien estimasi $(\beta)$ sebesar 0.68. Karena nilai $p$ value jauh lebih kecil dari nilai kritis $0.05(5 \%)$, terbukti secara statistik Implementasi SAK ETAP (SAK) berpengaruh positif dan signifikan 
terhadap Kualitas Laporan Keuangan (KLK). Artinya hipotesis 1 (H1) yang menyatakan terdapat pengaruh implementasi SAK ETAP terhadap kualitas laporan keuangan dapat diterima.

Berdasarkan hasil perhitungan uji SEM PLS menunjukan jalur SAK terhadap TKK dengan nilai $p$ value $<0.01$ dan nilai koefisien estimasi $(\beta)$ sebesar 0.52 . Karena nilai $p$ value jauh lebih kecil dari nilai kritis $0.05(5 \%)$, terbukti secara statistik Implementasi SAK ETAP (SAK) berpengaruh positif dan signifikan terhadap Tingkat Kesehatan Koperasi (TKK). Artinya hipotesis 2 (H2) yang menyatakan terdapat pengaruh implementasi SAK ETAP terhadap tingkat kesehatan koperasi dapat diterima.

Berdasarkan hasil perhitungan uji SEM PLS menunjukan jalur SAK terhadap TKK dengan nilai $\mathrm{p}$ value $<0.01$ dan nilai koefisien estimasi $(\beta)$ sebesar 0.46 . Karena nilai $\mathrm{p}$ value jauh lebih kecil dari nilai kritis 0.05 (5\%), terbukti secara statistik Implementasi SAK ETAP (SAK) berpengaruh positif dan signifikan terhadap Tingkat Kesehatan Koperasi (TKK). Artinya hipotesis 3 (H3) yang menyatakan terdapat pengaruh implementasi SAK ETAP terhadap tingkat kesehatan koperasi dapat diterima.

Untuk pengujian mediasi SEM-PLS dapat mengunakan metode VAF (Variance AccontedFor) dengan menggunakan rumus pengaruh tidak langsung (indirect effect) dibagi pengaruh total (total effect). Pengaruh total adalah pengaruh langsung ditambah dengan pengaruh tidak langsung). Jika nilai VAF diatas $80 \%$ KLK sebagai pemediasi penuh. Jika nilai VAF antara 20\%-80\% dikategorikan pemediasi parsial. Namun, jika VAF kurang dari $20 \%$ dikatakan hampir tidak ada efek mediasi (Hair dkk, 2013 dalam Sholihin dan Ratmono, 2013:82). Berikut ini disajikan hasil perhitungan nilai VAF dapat dilihat pada tabel di bawah ini:

Tabel 3.

Perhitungan VAF Jalur SAK-KLKTKK

Pengaruh tidak langsung $=0.68 * 0.46$ 0.31

\begin{tabular}{|l|c|}
\hline $\begin{array}{l}\text { Pengaruh SAK terhadap KLK }=0.68 \text { dan } \\
\text { pengaruh KLK terhadap TKK }=0.46\end{array}$ & \\
\hline $\begin{array}{l}\text { Pengaruh langsung } \\
\text { Pengaruh SAK terhadap TKK }=0.52\end{array}$ & 0.52 \\
\hline Total Pengaruh & 0,83 \\
\hline $\begin{array}{l}\text { VAF pengaruh tidak langsung/total pengaruh } \\
=0,31 / 0,83\end{array}$ & 0.37 \\
\hline
\end{tabular}

Sumber : Data diolah, 2019

Hasil perhitungan VAF

menunjukan nilai sebesar 0.37 atau $37 \%$.

Nilai $37 \%$ berada di antara 20\%-80\%, maka KLK memiliki efek mediasi secara parsial. Artinya hipotesis 4 (H4) yang menyatakan kualitas laporan keuangan memiliki pengaruh memediasi antara implementasi SAK ETAP dengan tingkat kesehatan koperasi diterima.

\section{Pembahasan}

\section{Terdapat Pengaruh Implementasi SAK ETAP (SAK) Terhadap Kualitas Laporan Keuangan (KLK).}

Implementasi SAK ETAP di koperasi Kota Tangerang dinilai baik. Hal ini diperoleh dari hasil survei sekitar $70 \%$ responden menjawab kesesuaian laporan keuangan koperasi tempat mereka bekerja dengan SAK ETAP. Hasil ini menunjukkan tingkat pemahaman pengurus koperasi akan pentingnya penerapan laporan keuangan lebih baik. Hal ini sejalan dengan penelitian hamdani dan aulia (2018) yang melakukan survei pemahaman pengurus atas SAK ETAP dengan hasil dikategorikan baik.

Hasil ini disebabkan karena pengurus koperasi yang menjabat lebih dari 5 tahun lebih banyak sehingga memungkinkan mereka bekerja lebih handal dan ahli dalam penyusunan laporan keuangan meskipun bukan berlatar belakang akuntansi.

Penyajian laporan keuangan koperasi bertujuan untuk memberikan informasi mengenai prestasi dan kondisi koperasi kepada para anggota koperasi dan masyarakat. SAK ETAP merupakan standar penyusunan laporan keuangan yang diperuntukkan untuk entitas tanpa akuntabilitas yang bertujuan menjaga kualitas laporan keuangan. Laporan keuangan koperasi yang disusun berdasarkan SAK-ETAP, akan membuat informasi yang disajikan menjadi lebih mudah dipahami, mempunyai relevansi, keandalan, dan mempunyai daya banding yang tinggi. Laporan keuangan koperasi yang tidak 
disusun berdasarkan standar dan prinsip yang berlaku, sebaliknya dapat menyesatkan pengunanya.

\section{Terdapat Pengaruh Implementasi SAK ETAP (SAK) Terhadap Tingkat Kesehatan Koperasi (TKK).}

Tingkat kesehatan koperasi di Kota Tangerang berdasarkan survei adalah menempati tingkat cukup sehat dengan total skor antara 66,0 - 80,0 dan rata2 skor berdasarkan survei adalah 70,0.

Dalam menjawab survei yang digunakan self administered survey yaitu menilai tingkat kesehatan berdasarkan jawaban2 responden terhadap kondisi keuangan dikoperasi tempat mereka bekerja. Penilaian tingkat kesehatan koperasi pada penelitian ini dinilai berdasarkan 7 (tujuh) kriteria dimana 6 (enam) dari kriteria tersebut didominasi oleh aspek keuangan antara lain aspek permodalan, aspek kualitas aktiva produktif, aspek efisiensi, aspek likuiditas, aspek kemandirian dan pertumbuhan serta aspek jatidiri koperasi. Dalam menilai kriteria atau aspek keuangan diperoleh data dari laporan keuangan.

Untuk dapat menjamin penilaian tingkat kesehatan koperasi yang benar maka harus diterapkan SAK ETAP dalam penyusunan laporan keuangan. Karena dengan proses penyusunan yang sesuai standar akan menghasilkan informasi laporan keuangan yang berkualitas. Selain memberikan informasi andal, mudah dipahami dan tidak menyesatkan, informasi keuangan yang disajikan berdasarkan SAK ETAP juga mampu meningkatkan tingkat kesehatan koperasi.

\section{Terdapat Pengaruh Kualitas Laporan Keuangan (KLK) Terhadap Tingkat Kesehatan Koperasi (TKK).}

Berdasarkan survei mengenai kualitas laporan keuangan, diperoleh hasil sebesar $40 \%$ responden menjawab bahwa laporan keuangan sangat sesuai dengan kriteria kualitatif dari laporan keuangan. Sebesar 40\% menjawab sesuai dan sisany menjawab cukup sesuai. Hasil ini menunjukkan berdasarkan self administered survei, laporan keuangan koperasi di Kota Tangerang sudah memenuhi karakteristik kualitas laporan keuangan.

Kesadaran mengenai pentingnya laporan keuangan yang berkualitas sudah baik karena laporan keuangan merupakan pertanggung jawaban pengurus yang akan disampaikan dalam Rapat Anggota Tahunan (RAT). Karena akan digunakan oleh para anggota dan manajemen untuk membuat keputusan ekonomis. Untuk dapat menghasilkan keputusan yang tepat maka dalam pembuatan laporan keuangan yang berkualitas Laporan keuangan koperasi yang disusun berdasarkan SAK-ETAP, akan membuat informasi yang disajikan menjadi lebih mudah dipahami, mempunyai relevansi, keandalan, dan mempunyai daya banding yang tinggi (IAI, 2015).

Laporan keuangan yang berkualitas, maka ketidakseimbangan perolehan informasi antara pihak pengelola sebagai penyedia informasi dengan pihak pemilik dan stakeholder pada umumnya sebagai pengguna informasi (user) akan semakin berkurang (Fanani, 2009). Hasil penelitian Sakti dan Septiani (2015) menunjukkan bahwa kualitas informasi pelaporan keuangan mempunyai pengaruh yang signifikan terhadap menandai informasi mereka mengenai kesempatan efisiensi investasi. Kualitas pelaporan keuangan yang tinggi juga memungkinkan manajer untuk membuat keputusan investasi melalui identifikasi proyek yang lebih baik dan menyajikan angka-angka akuntansi yang lebih tepat guna pembuatan keputusan internal (Bushman dan Smith, 2001; McNichols dan Stubben, 2008 dalam Sakti dan Septiani, 2015).

4. Terdapat Pengaruh Implementasi SAK ETAP (SAK) terhadap Tingkat Kesehatan Koperasi (TKK) yang dimediasi oleh Kualitas Laporan Keuangan (KLK).

Implementasi SAK ETAP secara tidak langsung merupakan indikator informasi laporan keuangan yang berkualitas. Tanpa kualitas laporan keuangan penerapan SAK ETAP akan menjadi sekedar pemenuhan kewajiban saja. Dari informasi yang 
berkualitas, penilaian tingkat kesehatan koperasi lebih terjamin keandalannya.

\section{KESIMPULAN DAN REKOMENDASI Kesimpulan}

Berdasarkan hasil pengujian hipotesis yang telah dipaparkan di atas, maka dapat dibuat kesimpulan sebagai berikut:

1. Implementasi SAK ETAP pada koperasi di Kota Tangerang masuk kategori baik. 70\% jawaban responden menyatakan kesesuaian laporan keuangan dengan SAK ETAP. Implementasi SAK ETAP positif dan signifikan terhadap Kualitas Laporan Keuangan. SAK ETAP sebagai standar penyusunan laporan keuangan dapat meningkatkan kualitas laporan keuangan koperasi di Kota Tangerang.

2. Implementasi SAK ETAP berpengaruh positif dan signifikan terhadap Tingkat Kesehatan Koperasi. Hal ini dibuktikan bahwa implementasi SAK ETAP di Kota Tangerang sudah baik sehingga tingkat kesehatan koperasi di kota Tangerang juga cukup baik. Skor tingkat kesehatan koperasi menunjukkan nilai rata-rata sebesar 70,0 yaitu berada dalam kategori cukup sehat.

3. Kualitas Laporan Keuangan berpengaruh positif dan signifikan terhadap Tingkat Kesehatan Koperasi. Pemahaman atas kualitas informasi yang disampaikan melalui laporan keuangan mendorong terjaminnya penilaian atas tingkat kesehatan koperasi. Dari informasi yang berkualitas, penilaian kesehatan koperasi dapat diterima.

4. Kualitas Laporan Keuangan memoderasi pengaruh Implementasi SAK ETAP terhadap Tingkat Kesehatan Koperasi. Dibuktikan dengan nilai VAF sebesar 37\% yang menunjukkan bahwa KLK memiliki efek mediasi secara parsial. Artinya Tingkat kesehatan Koperasi dipengaruhi oleh implementasi SAK ETAP melalui kualitas laporan keuangan.

\section{Keterbatasan}

Keterbatasan dalam penelitian ini antara lain :

1. Penelitian mengenai implementasi SAK ETAP pada koperasi masih sangat sedikit dilakukan sehingga referensi penelitian terdahulu sangat terbatas.

2. Jumlah sampel penelitian masih tergolong kecil dibandingkan dengan jumlah koperasi di Kota Tangerang.

3. Keterbatasan selanjutnya adalah variabel yang dipilih terbatas pada bidang akuntansi, sehingga belum mampu menjawab masalah yang dihadapi oleh koperasi di Kota Tangerang.

\section{Rekomendasi}

Berdasarkan hasil temuan penelitian ini bahwa pengurus koperasi di Kota Tangerang sebagian besar bukan berlatar belakang pendidikan akuntansi, sehingga tetap harus dilakukan pendampingan dan pelatihan akuntansi bagi koperasi berbasis SAK ETAP. Sosialisasi SAK ETAP bagi pengurus dan karyawan koperasi perlu juga dilakukan dengan melibatkan pengurus IAI, perguruan tinggi dan dan para praktisi akuntansi koperasi untuk mensikapi segala permasalahan yang saat ini dihadapi oleh koperasi yang ada di Kota Tangerang.

\section{DAFTAR PUSTAKA}

Adiputra, I Made Sujana, Sinarwati, Ni Kadek dan Purnamawati, Gusti Ayu. 2017. Pengaruh Pemahaman Akuntansi Berbasis Sak-Etap, Kualitas Pelatihan, Dan Sistem Pengendalian Internal Terhadap Kualitas Laporan Keuangan Koperasi (Studi Empiris Pada Koperasi Simpan Pinjam di Kecamatan Karangasem). e-Journal S1 Ak Universitas Pendidikan Ganesha. Jurusan Akuntansi Program S1(Vol: 8 No: 2 Tahun 2017).

Afandi, Pandi. 2017. Analisis Kinerja Keuangan Untuk Mengukur Kesehatan Keuangan Koperasi KSU BMT Arafah Kecamatan Bancak Kabupaten Semarang. Among Makarti, Vol.7 No.13, Juli 2014.

Eindrias, Tri., Dewi dan Ajizah, Dewi F. 2017. Analisa Tingkat Kesehatan Koperasi Simpan Pinjam Berdasarkan Peraturan Nomor: 06/PER/DEP.6/IV/2016 (Studi 
Pada Koperasi Simpan Pinjam Bahagia Kota Kediri). Jurnal Administrasi Bisnis (JAB)|Vol. 51 No. 2 Oktober 2017| administrasi bisnis. Student journal.ub.ac.id E-ISSN: 2548-9836, Accepted November, 2017

Fanani, Z. 2009. Kualitas Pelaporan Keuangan: Berbagai Faktor Penentu Dan Konsekuensi Ekonomis. Jurnal Akuntansi dan Keuangan Indonesia. 6: 20- 45

Ghozali, Imam dan Latan, Hengky. 2014. Partial Least Squares (PLS), Konsep, Metode, dan Aplikasi Menggunakan Program Warppls 4.0. Badan Penerbit Fakultas Ekonomi Undip: Semarang.

Ghozali, Imam. 2014. Structural Equation Modeling Metode Alternatif dengan Partial Least Squares (PLS). Badan Penerbit Fakultas Ekonomi Undip: Semarang.

Hamdani dan Aulia, Triana Zuhrotun. 2018. The Perceptions of Cooperative Management on the Understanding of Financial Statements to the Punctuality in Conducting the Annual Members. Journal of Finance and Accounting Volume 6, Issue 3, May 2018, Pages: 84-90

Hetika dan Mahmudah, Nurul. 2017. Penerapan Akuntansi Dan Kesesuaiannya Dengan SAK ETAP Pada UMKM Kota Tegal. Jurnal Akuntansi, Ekonomi dan Manajemen Bisnis. Vol. 5, No. 2, December 2017, 259-266. Received October,2017

http://tangerangnews.com/kotatangerang/read/ 22975/Koperasi-di-Kota-Tangerang

Tergerus-Minimarket (diakses tanggal 20 Agustus 2018).

https://nik.depkop.go.id/, (diakses tanggal 20 Agustus 2018)

Ikatan Akuntansi Indonesia. 2015. Standar Akuntansi Keuangan Entitas Tanpa Akuntabilitas Publik. Jakarta: Dewan Standar Akuntansi Keuangan

Khikmah dan Yuliani. 2013. Persepsi pelaku UKM terhadap Standar Akuntansi Keuangan (SAK) ETAP guna peningkatan kinerja perusahaan.
Penelitian Dosen Pemula Universitas Muhammadiyah Magelang.

Kusuma, M dan Budianto, H. 2013. Pengaruh pemahaman akuntansi koperasi berbasis SAK-ETAP terhadap kualitas penyusunan laporan keuangan koperasi. Cahaya Aktiva Vol.03 No.2, Halaman 81-91

Martani, Dwi. 2015. Standar Akuntansi Keuangan Entitas Tanpa Akuntabilitas Publik (SAK ETAP). Diambil dari: http://dwimartani.com/sak-etap-detil/ (diakses tanggal 22 Agustus 2018)

Muzahid, Mukhlisul. 2013. Pengaruh Tingkat Pendidikan, Kualitas Pelatihan, dan Lama Pengalaman Kerja Pegawai Terhadap Kualitas Laporan Keuangan Satuan Kerja Perangkat Daerah (SKPD) di Kabupaten Aceh Utara. E-Jurnal. Universitas Riau.

Peraturan Menteri Negara Koperasi dan Usaha Kecil dan Menengah Nomor 04/Per/M.KUKM/VII/2012 Tentang Pedoman Akuntansi Koperasi Kementerian Koperasi Dan Usaha Kecil Dan Menengah Republik Indonesia.

Peraturan Menteri Negara Koperasi dan Usaha Kecil dan Menengah Nomor 04/Per/M.KUKM/VII/2012 Tentang Pedoman Akuntansi Koperasi Kementerian Koperasi Dan Usaha Kecil Dan Menengah Republik Indonesia.

Peraturan Menteri Negara Koperasi dan Usaha Kecil dan Menengah Republik Indonesia No. 35.2/Per/M.KUKM/X/2007 tentang Pedoman Standar Operasional Manajemen Koperasi Jasa Keuangan Syariah dan Unit Jasa Keuangan Syariah Koperasi.

Pratiwi, Sondakh J, \& Kalangi. 2014. Analisis Penerapan SAK ETAP Pada Penyajian Laporan Keuangan PT. Nichindo Manado Suisan.

Sakti, Alisya Misitama dan Septiani, Aditya. 2015. Pengaruh Kualitas Pelaporan Keuangan dan Jatuh tempo utang terhadap efisiensi investasi. Diponegoro Journal of Accounting Volume 4, Nomor 2, Tahun 2015, Halaman 1-10. ISSN (Online): 2337-3806. http://ejournals1.undip.ac.id/index.php/accounting 
Sarifah, Hani' atun. 2012. Penerapan Akuntansi Berdasarkan SAK ETAP pada UKM Kampung Batik Sidoarjo.

Sholihin M. dan Ratmono D. 2013. Analisis Structural Equation Modeling Partial Least Squares (PLS) dengan Warppls 3.0 untuk Hubungan Non linier Dalam Penelitian Sosial dan Bisnis. CV. Andi Offcet: Yogyakarta.

Sukmana, A., \& Mulyati, S. (2017). Penilaian Kesehatan KJKS BMT Binamas. Jurnal akuntansi dan keuangan islam, 3(2). Retrieved from https://jurnal.sebi.ac.id /index.php/jaki/article/view/50

Suwardjono. 2013. Teori Akuntansi Perekayasaan Pelaporan Keuangan. Yogyakarta: BPFE-Yogyakarta.

Undang-Undang Republik Indonesia Nomor 25 Tahun 1992 Tentang Perkoperasian.

Veronica, S., \& Rudiantoro, R. 2011. Kualitas Laporan Keuangan UMKM serta Prospek Implementasi SAK ETAP. Jurnal Simposium Nasional Akuntansi XIV, 2-3

Weygandt, Kimmel and Kieso. 2013. Financial Accounting: IFRS Edition. Hoboken: John Wiley \& Sons, Inc.

Wicaksono, A. 2013. Persepsi Anggota dan Kompetensi Pengurus Koperasi Terhadap Penyusunan Laporan Keuangan Koperasi Berdasarkan SAK ETAP di KP-RI "Guru" Kecamatan Talun Kabupaten Blitar. Jurnal Riset Mahasiswa Akuntansi Universitas Kanjuruhan Malang. Vol 1, No 1.http://ejournal.unikama.ac.id/index. php /jrma/article/view/11 (diakses pada tanggal 23 Agustus 2018). 